Elżbieta Michałowska

Katedra Socjologii Wsi i Miasta

Wydział Ekonomiczno-Socjologiczny

Uniwersytet Łódzki

\title{
KSZTAŁCENIE SOCJOLOGÓW
}

\section{Wprowadzenie}

Jednym z podstawowych pytań, które zadają nam różni specjaliści rynku, a także studenci, brzmi następująco: Jaki profil absolwenta studiów socjologicznych jest najbardziej pożądany na polskim i europejskim rynku pracy, zatem jak kształcić socjologów, żeby na te wyzwania współczesnego rynku pracy odpowiedzieli?

Myślę, że dobrym wprowadzeniem będzie kilka przykładowych wypowiedzi absolwentów łódzkiej socjologii oceniających przydatność studiów socjologicznych w kształtowaniu swoich ścieżek karier zawodowych:

1. Socjologia jest kierunkiem dla osób, które chciałyby nauczyć się myśleć nietuzinkowo, szeroko patrzeć na otaczającą rzeczywistość. Podczas studiów miałem okazję uczęszczać na zajęcia poświęcone gospodarce, polityce czy kulturze, co w momencie kończenia studiów dawało mi możliwość ułożenia ścieżki kariery w kilku kierunkach i otwierało horyzonty na różne dyscypliny.

2. [...] absolwenci socjologii odnajdują się na rynku pracy świetnie. Kiedy patrzę na kolegów ze studiów, z którymi nadal utrzymuję kontakt, widzę ludzi pracujących jako kierownicy projektów, dziennikarze, wykładowcy, bankowcy, rzecznicy prasowi, marketingowcy i w wielu innych zawodach. Potrafimy rewelacyjnie zaadaptować się do sytuacji na rynku pracy. Wynika to chyba z faktu, iż nie są to studia ścisłe i odtwórcze, ale takie, które uczą myślenia i poszukiwania informacji na zewnątrz.

3. Socjologia wpaja szerszy horyzont myślowy i dużą elastyczność w nabywaniu pewnych umiejętności. Przygotowanie ściśle zawodowe dały mi dopiero studia podyplomowe z zakresu PR. Natomiast pewien podkład mentalny, umiejętności z zakresu np. komunikowania, radykalny 
krytycyzm zawdzięczam z kolei socjologii i nieocenionej swobodzie myślowej, sokratejskiej otwartości umysłów moich mentorów, niezawisłości poglądów tak często nieobecnej na uczelniach, a stanowiącej myśl przewodnią Zamkniętego umystu Blooma. Jeśli zatem pytanie brzmi, czy pracuję w swoim zawodzie jako absolwent specjalizacji Kultura, komunikowanie i media, to ogólnie mogę powiedzieć, że tak, bo zajmuję się Public Relations, w łódzkim banku zresztą ${ }^{1}$.

Jednak, aby zrównoważyć te niezwykle optymistyczne opinie naszych absolwentów, przytoczę wyniki badań, które przeprowadziła wśród studentów Uniwersytetu Łódzkiego Marta Welfe-Starzak. Autorka stwierdziła na koniec swojej analizy m.in., że kluczowym motywem w trakcie podejmowania przez młodych ludzi decyzji o kształcie ich dalszej edukacji na poziomie wyższym jest chęć znalezienia pracy po ukończeniu studiów.

Dla przyszłych studentów ważne są również ich zainteresowania i to głównie one decydują o wyborze konkretnego kierunku studiów. Inne konkluzje z cytowanych badań:

1. Badani negatywnie oceniają studia. Tylko około połowy badanych (54\%) deklaruje, że studia spełniły ich oczekiwania. Co więcej, około połowy badanych (53\%) jest zdania, że studia nie przygotowują ich do zadań, przed którymi staną lub już stanęli w pracy. Przeciwnego zdania jest jedynie 8\% respondentów;

2. Można przypuszczać, że to właśnie niezadowolenie ze studiów oraz przeświadczenie żywione przez większość badanych, że to doświadczenie i kwalifikacje zawodowe są kluczem do znalezienia zatrudnienia, sprawia, że studenci są aktywni na różnych polach, ponieważ ponad połowa (57\%) pracuje w trakcie studiów (Welfe-Starzak 2011).

Pracując nad konstrukcją programów studiów socjologicznych w zgodzie z Krajowymi Ramami Kwalifikacji, zadałam sobie pytanie: jak powinna wyglądać sylwetka absolwenta socjologii i w jaki sposób przełożyć ją na nowoczesne programy nauczania? Czy możliwy jest taki program kształcenia, który zaspokajałby rynkowe zapotrzebowania na socjologów? Powyższe wypowiedzi świadczą o tym, że to, co robiliśmy do tej pory, nie dość satysfakcjonująco wpisywało się w potrzeby rynkowe. Uczestniczyłam w wielu szkoleniach organizowanych dla pracowników wyższych uczelni zajmujących się pracą nad zmianami programowymi, które w moim przekonaniu powinny były zaprezentować nową filozofię studiowania i kształcenia w oparciu o KRK, czyli odpowiedzieć na pytania: dlaczego tak będzie lepiej, kreatywniej, a de facto przekazywano nam

${ }^{1}$ Wypowiedzi absolwentów pochodzą ze strony Wydziału Ekonomiczno-Socjologicznego, zakładka absolwenci o studiach (maj 2013). 
informacje jak, nie dlaczego? Nie było zatem możliwości dyskusji, poszukiwania własnych rozwiązań, a w zamian dano nam matrycę. A socjologowie podejmowali próby negocjowania tych kwestii w ramach Konferencji Instytutów Socjologii, której niezwykle aktywnie przewodniczyła prof. Jolanta Kulpińska, ale niespecjalnie się to przełożyło na realne wymiary aplikacyjne.

Studia dwustopniowe od początku przyjmowane były raczej z niechęcią, nierzadko postrzegane jako „europejska fanaberia” i źródło obniżania poziomu kształcenia. Poprzez swego rodzaju automatyzm wprowadzania studiów dwustopniowych, jako „innej nazwy” dla klasycznej formuły studiów pięcioletnich, zdeformowano cykl kształcenia. Ponadto system ECTS nierzadko charakteryzuje brak zrozumienia, wspominany automatyzm, czynniki niemerytoryczne w przypisywaniu liczby punktów zajęciom itd. Do tego praktyki - przykry i nie dający się zrealizować obowiązek, a nie niezwykle ważny element kształcenia.

Chciałabym podjąć dwie kwestie, które w istotnym zakresie wymagają dyskusji:

1. Nauczyciele akademiccy wobec zmiany filozofii kształcenia.

2. Kształcenie dwustopniowe.

\section{Nauczyciele akademiccy wobec zmiany filozofii kształcenia}

Bardzo istotnym problemem w kwestii nowej filozofii kształcenia są trudności wśród kadry dydaktyków. Myślę, że podstawowym zadaniem i jednocześnie trudnością we wdrażaniu nowoczesnego kształcenia jest zmiana warsztatu nauczycieli akademickich. Ważniejsze jest nie samo przekazywanie wiedzy, ale jej skuteczna aplikacja studentom, których mamy uczyć kreatywności i samodzielności. Oczywiście wiadomo, że znaczna liczba studentów nie powinna nimi zostać, ale jest to efekt reformy szkolnictwa średniego, a w konsekwencji i znaczącego obniżenia oczekiwań wobec maturzystów, a my nie jesteśmy w stanie i zresztą nie jest to zadanie uniwersytetów nadrabianie zaniedbań edukacyjnych.

Oczekiwania wobec nauczycieli akademickich są skierowane na „nasycenie” studentów wiedzą praktyczną i teoretyczną. Tak więc dużą część programu powinny stanowić zajęcia w małych grupach, w bezpośrednim kontakcie między studentem a prowadzącym, co w założeniach ma prowadzić do wykształcenia myślenia problemowego, zorientowanego na aktywne szukanie rozwiązań analizowanego problemu i to może napotkać na największy opór. 
Zatem konieczna jest modyfikacja bądź wręcz zmiana dotychczasowego warsztatu pracy, jej metodyki, co zajmie bardzo dużo czasu. Klasyczny przekaz informacji utrwala bierną postawę studenta jako odbiorcy, nie zawsze konsumenta przekazywanej wiedzy. Ponadto sądzę, że konieczna jest jednak akceptacja kadry akademickiej dla faktu, że absolwent nie umie wszystkiego, (ale umie myśleć, uczyć się i działać), ponadto absolwenci tego samego kierunku mają różne kompetencje i że niewielka liczba absolwentów jest „prawdziwymi” fachowcami w swojej dziedzinie.

\section{Kształcenie dwustopniowe}

Właściwie wprowadzenie studiów dwustopniowych musi bowiem oznaczać zupełnie nowe rozumienie celów i organizacji kształcenia. W założeniu studia dwustopniowe miały pozwolić na dowolne kształtowanie długości studiów (system zaliczeń semestralnych/rocznych, który miał zastąpić akumulowanie punktów), elastyczne kształtowanie programów studiów, w znacznej mierze dostosowanych do indywidualnych potrzeb, co przejawiać ma się w kształceniu modułowym, wybieranym i profilowanym przez indywidualnego studenta - uznawanie kwalifikacji zdobytych poza systemem uczelni wyższych (akademickich). Studia dwustopniowe z perspektywy studenta miały umożliwić zakończenie kształcenia już po I stopniu i podjęcie pracy, stwarzać miały również przerwanie kształcenia na I stopniu i powrót na studia po pewnym czasie, ich zaletą także miało być uelastycznienie procesu studiowania, mobilność studentów pomiędzy uczelniami i kierunkami studiów, a także zwiększenie dostępu do studiów. Takie były plany i zamierzenia, a jakie mamy dzisiaj problemy i wątpliwości?

Czy istnieje coś takiego jak praktyczny (a może zawodowy) i teoretyczny profil studiów socjologicznych? A może tak, jak na niektórych kierunkach socjologicznych, stopień I to studia uniwersalne, wyczerpujące pola wiedzy ogólnej, zaś stopień II pogłębienie i uszczegółowienie studiów poprzez nacisk na pracę w małych grupach, angażowanie studentów do realizacji projektów badawczych, zachęcanie do poszukiwania praktycznych rozwiązań problemów społecznych, które obudowane będą rzetelną wiedzą akademicką? I w tym zakresie nie ma jeszcze wypracowanych dobrych praktyk, cały czas ,grzebiemy” w programach, zmieniając je, „okrawając”, nie myśląc o podstawowych kwestiach uniwersalnych, metodyce projektowania programów studiów czy modelu studiowania. 
System boloński przyniósł nam ów dwustopniowy model studiów, a wpisana w jego specyfikę mobilność studentów, a w konsekwencji otwarcie kierunków na napływ na II stopień studentów spowodowała, że niektórzy nie mają za sobą merytorycznego i metodologicznego przygotowania z zakresu socjologii. Pojawił się problem, jak przygotować programy studiów socjologicznych, by absolwenci innych kierunków studiów I stopnia, z korzyścią dla siebie mogli studiować socjologię?

Już kilkoro absolwentów, którzy ukończyli inne niż socjologia kierunki studiów, może uniemożliwić, ze względu na zróżnicowany poziom wiedzy i kompetencji, prowadzenie zajęć. Czy dobrym rozwiązaniem jest powołanie do życia tzw. zajęć wyrównawczych - poza programem studiów II stopnia? Jak tę kwestię rozwiązać organizacyjnie, jak odnieść je do obciążeń studentów wynikających z programu studiów? Czy miałyby to być zajęcia dodatkowe - obowiązkowe? Jestem dość sceptyczna w kwestii zajęć wyrównawczych - nie wobec samej idei, ale organizacyjnych aspektów ich wdrażania, biorąc pod uwagę wzrastającą dyscyplinę samoograniczania, jak również gotowość studentów do uczestnictwa $\mathrm{w}$ nich, uznając, że byłyby one realizowane poza podstawowym programem nauczania - a skoro tak, to w jaki sposób rozliczać pensum dydaktyczne? Być może rozwiązaniem byłoby przeprowadzenie selekcji na II stopień w formie chociażby rozmowy kwalifikacyjnej - co praktykują niektóre uczelnie w Polsce, a co zmotywowałoby studentów do przeczytania listy lektur.

A jeśli już mowa o postępowaniu kwalifikacyjnym - rekrutacji, to warto byłoby rozważać choćby minimalny wkład - poza maturą - przyszłego studenta w aplikowanie do przyjęcia na kierunek - co jest w różny sposób praktykowane na uczelniach europejskich czy amerykańskich - np. list intencyjny, esej, aplikacja motywująca wybór kierunku itp. - co ma zresztą niezwykle duże znaczenie w przyjęciu na uczelnie amerykańskie, holenderskie czy brytyjskie, gdzie obowiązuje Personal Statement (PS), odpowiednik życiorysu i listu motywacyjnego, potrzebne są niekiedy także referencje wychowawcy, nauczyciela itp. To zmusiłoby przyszłego studenta do uświadomienia sobie odpowiedzialności w zakresie wyboru kierunku, przemyślenia decyzji i jej konsekwencji.

\section{Podsumowanie}

Studia wyższe w dalszym ciągu stanowią przepustkę do kariery zawodowej, ale już nie gwarantują uzyskania zawodowych kwalifikacji, zapewniających pracę określoną kierunkiem studiów. Ich zasadniczym celem jest zapewnienie wiedzy i wykształcenie umiejętności przydatnych w procesie edukacji przez całe 
życie i adaptacji do zmieniających się wymagań rynku pracy. Podstawową kwestią, która powinna być zasadniczą dyrektywą kształcenia akademickiego, jest fakt, że absolwent socjologii powinien raczej umieć reagować na rynek, a nie odpowiadać na potrzeby rynku. Poszukiwani są raczej kandydaci, którzy potrafią połączyć wiedzę i umiejętności z wielu obszarów i dziedzin. O tym wiedzą także aktywni studenci, którzy w skrajnych formach studiują równolegle kilka kierunków - nawet 3-4 - żeby być przygotowanym na te różnorodne wyzwania rynku. Dodatkowo, aby można uznać profesjonalizm zawodu socjologa, zgodnie z ustaleniami socjologii zawodu, trzeba uwzględnić dodatkowe elementy: nastawienie na służbę społeczeństwu, kontrola grupy (organizacji) zawodowej, charakterystyczny etos (kultura i etyka), poczucie przynależności do zawodu i identyfikowanie przez innych (np. klientów, opinię publiczną), (Kulpińska 2005: 174).

Socjologia jest takim kierunkiem studiów, który może znakomicie rozwijać zdolności adaptacyjne absolwenta do zmieniającej się rzeczywistości. Moim zdaniem, na ten aspekt powinniśmy położyć nacisk, czyli dostarczać wiedzę ogólnoakademicką, rozwijać zdolności adaptacyjne i elastyczność oraz rozwijać zdolności komunikacyjne i pracę w grupach. Do tego kompetencje w zakresie nowych technologii pozwolą na owo umiejętne reagowanie na rynek pracy.

\section{Bibliografia}

Kulpińska J.(2005), Dylematy dwustopniowych studiów w dyskusjach socjologów, [w:] J. Dietl, Z. Sapijaszka (red.), Dylematy studiów dwustopniowych, Wydawnictwo Fundacji Edukacyjnej Przedsiębiorczości, Łódź.

Welfe-Starzak M. (2011), Opinie studentów Wydziału Ekonomiczno-Socjologicznego UŁ na temat studiów i rynku pracy, [w:] A. Rogozińska-Pawełczyk, D. Majewski (red.), Absolwent na rynku pracy, Wydawnictwo UŁ, Łódź. 